\title{
Role of Antioxidant-Rich Nutraceutical on Body Weights and Mean Arterial Blood Pressure of Salt-Induced
} Hypertensive Rats

\author{
Lawal N1*, Bilbis LS², Umar $\mathrm{RA}^{2}$ and Sabir $\mathrm{AA}^{3}$ \\ ${ }^{1}$ Department of Biochemistry \& Molecular Biology, Federal University, Nigeria \\ 2Department of Biochemistry, Usmanu Danfodiyo University, Nigeria \\ ${ }^{3}$ Department of Medicine, Usmanu Danfodiyo University Teaching Hospital \\ Sokoto, Nigeria
}

*Corresponding author: Dr. Lawal Nura, Department of Biochemistry \& Molecular Biology, Federal University, Dutsinma Katsina state, Nigeria, Tel: 2348035869434; E-mail: nlbatagarawa@gmail.com

\section{Research Article \\ Volume 2 Issue 1}

Received Date: November 18, 2017

Published Date: November 30, 2017

\section{Abstract}

Hypertension or high blood pressure is a medical condition in which blood pressure in the vessels is persistently elevated. The study aim to formulate an antioxidant rich nutraceutical from locally available food stuff (onion, garlic, ginger, tomato, lemon, palm oil, water melon seeds) and investigate their effects on blood pressure and body weight in salt-induced rats. The rats were placed on $8 \%$ salt diet for 6 weeks and then supplementation and treatment with nutraceutical and nifedipine in the presence of salt diet for additional 4 weeks. Feeding rats with salt diet for 6 weeks increased blood pressure and body weight of the salt-loaded rats relative to control. Both supplementation and treatment (nifedipine) lowered the blood pressure but only supplementation lowered the body weight. Antioxidantrich nutraceutical might be beneficial in the managements of patients with hypertension and obesity.

Keywords: Supplementation; High Blood Pressure; Vessels; Obesity; Nifedipine

Abbreviations: BP: Blood Pressure; STG: Standard Treatment Guidelines; SBP: Systolic Blood Pressure; DBP: Diastolic Blood Pressure; MABP: Mean Arterial Blood Pressure; PR: Pulse Rate; RAAS: Renin Angiotensin Aldesterol System; MR: Mineralocorticoid Receptors; ROS: Reactive Oxygen Species; ACE: Angiotensin Converting Enzyme

\section{Introduction}

Hypertension is the major public health problem worldwide and it is among the common cardiovascular disease in black Africans and a major cause of morbidity and mortality among Nigerians [1]. According to hypertension is a condition in which the systolic blood pressure (BP) equal is greater than $140 \mathrm{mmHg}$ or diastolic blood pressure equal or greater than $90 \mathrm{mmHg}$ [2].

Excess of sugar and salt or deficiencies of antioxidant vitamins in diet play a vital role in the etiology of hypertension which directly poses damage to the vital organs such as brain, kidney and vascular tissues [3].

Hypertension represents one of the major factors for the development and progress of cardiovascular diseases and it is an important threat to the health of individuals in sub - Saharan Africa [4]. 


\section{International Journal of Biochemistry \& Physiology}

The prevalence of hypertension varies within different countries. The overall global prevalence among adults was estimated to be $26.6 \%$ in men and $26.1 \%$ in women [5].

In Nigeria, hypertension is the commonest noncommunicable disease with over 4.3 million Nigerians above the age of 15 years classified as being hypertensive (systolic BP $\geq 160 \mathrm{mmHg}$ and diastolic BP $\geq 90 \mathrm{mmHg}$ ). This gives a prevalence rate of about $25 \%$ which is even higher when the current standard treatment guidelines (STG) of $\geq 140$ and $\geq 90 \mathrm{mmHg}$ systolic and diastolic BPs respectively, are used as a landmark [6]. Prevalence rates of this magnitude place a significant burden on the limited health facilities of developing countries.

Furthermore, epidemiological studies and clinical trials suggested that, diets known to contain significant amount of naturally occurring antioxidants appear to ameliorate most of the traits of metabolic syndrome and may reduce cardiovascular risk [7]. Some locally available foodstuff contains significant amount of antioxidants and may be use for formulation of an antioxidant rich nutraceutical.

The research was conducted to determine the effect of salt diet on body weight and blood pressure in albino rats at 6 weeks of salt loading and to evaluate the effects of antioxidants rich nutraceutical on body weight and blood pressure of salt induced hypertensive rats.

\section{Materials and Methods}

\section{Experimental Animals}

Wistar albino rats of both sexes weighing between 150-220g were used for the study. The animals were purchased from the Department of Biological Science, Usmanu Danfodiyo University, Sokoto, Nigeria and were allowed to acclimatize for two weeks before the commencement of the experiment. The animals were grouped into 6 groups of eight rats each and were fed with pelletized growers' feed (Vital feed, Jos, Nigeria) and allowed access to water ad libitum before and during the experimental period.

\section{Experimental Design}

The animals were randomly divided into 6 groups of eight rats each.

Group I Salt-loaded, treated with $250 \mathrm{mg} / \mathrm{kg}$ of nutraceutical

Group II Salt-loaded, treated with $500 \mathrm{mg} / \mathrm{kg}$ of nutraceutical

Group III Salt-loaded, treated with $10 \mathrm{mg} / \mathrm{kg}$ of nifedipine
Group IV Salt-loaded, treated with $500 \mathrm{mg} / \mathrm{kg}$ of nutraceutical $+10 \mathrm{mg} / \mathrm{kg}$ of nifedipine

Group V Salt-loaded, untreated

Group VI Normal, control

\section{Induction of Hypertension in Rats}

The rats were placed on $8 \% \mathrm{w} / \mathrm{w}$ salt diet except the control group, for 6 weeks and treatment with nutraceutical for additional 4 weeks [8].

\section{Measurement of Blood Pressure}

The baseline blood pressure was measured by tailcuff method using non-invasive Ugo Basile, series 58500 blood pressure recorder. The average of three readings was taken for each rat and the blood pressure of the rats were monitored throughout the experimental period. Mean arterial blood pressure was calculated according to the following equation: DP $+1 / 3$ (SP-DP) where SP and DP are systolic and diastolic pressure respectively. Subsequent measurements were done every week.

\section{Preparation of Antioxidant Micronutrients Supplements}

The nutraceutical was prepared from onions, garlic, tomatoes, ginger, water melon seeds, lemon and palm oil in ratio of $4: 4: 4: 4: 2: 1: 1$. This was done by mixing $20 \mathrm{~g}$ of onions; $20 \mathrm{~g}$ of garlic, $20 \mathrm{~g}$ of tomatoes and $20 \mathrm{~g}$ of ginger in $100 \mathrm{ml}$ distilled water and blended using electric blender. $10 \mathrm{~g}$ of ground water melon seeds were then added and blended once again. To this, $5 \mathrm{~g}$ of lemon juice and $5 \mathrm{~g}$ of palm oil were added, mixed. The nutraceutical solution was packaged into clean dry containers and stored frozen at $-20^{\circ} \mathrm{C}$ until required.

The appropriate dosages of the nutraceutical and drug were administered to the animals orally once daily by intubation using intravenous cannula tube for 4 weeks, weight changes of the rats were monitored throughout the experimental period.

\section{Estimation of $\%$ Protection against Atherogenesis}

This was calculated using the following equation:

$$
\% \text { protection }=\frac{\text { AI of } H C-\text { AI of treated group }}{A I \text { of } H C} \times
$$

\section{Statistical Analysis}

Values are expressed as mean \pm standard deviation of 6 rats per group. 


\section{International Journal of Biochemistry \& Physiology}

\section{Results}

The effect of nutraceutical on systolic blood pressure (SBP), diastolic blood pressure (DBP), mean arterial blood pressure (MABP) and pulse rate (PR) are presented in Figures 1, 2, 3 and 4 respectively. The result indicated that salt-loading to rats for 6 weeks increased the SBP, MABP and PR but no variation on DBP between salt-loading groups and control group. Supplementation with nutraceutical lowered the SBP, MABP and PR. The salt loading untreated group showed a progressive increase of SBP, MABP and PR throughout the experimental period while controls group no increase was observed.

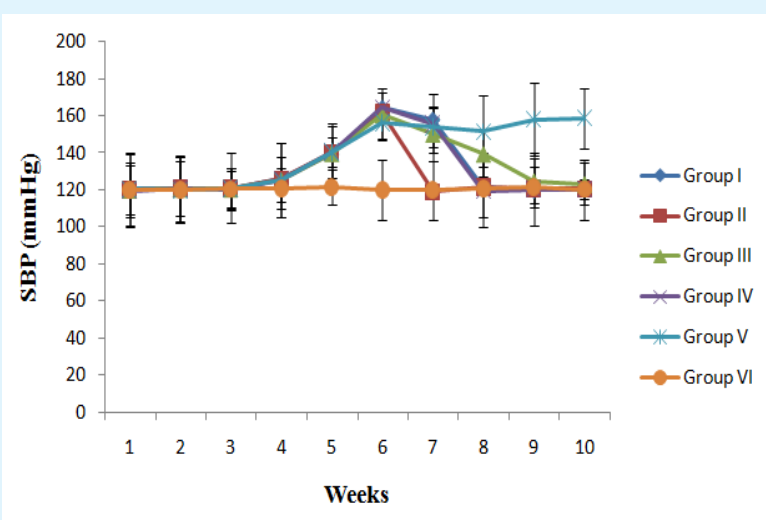

Figure 1: Effect of salt diet and nutraceutical supplementation on systolic blood pressure of saltloaded rats

Week 1-6: salt diet only, week 6-10: salt diet plus supplements, Group I: salt loaded treated with $250 \mathrm{mg} / \mathrm{kg}$ of nutraceutical, Group II: salt loaded treated with $500 \mathrm{mg} / \mathrm{kg}$ of nutraceutical, Group III: salt loaded treated with $10 \mathrm{mg} / \mathrm{kg}$ of nifedipine, Group IV: salt loaded treated with $500 \mathrm{mg} / \mathrm{kg}$ of nutraceutical + $10 \mathrm{mg} / \mathrm{kg}$ of nifedipine, Group V: salt-loaded untreated, Group VI: control.

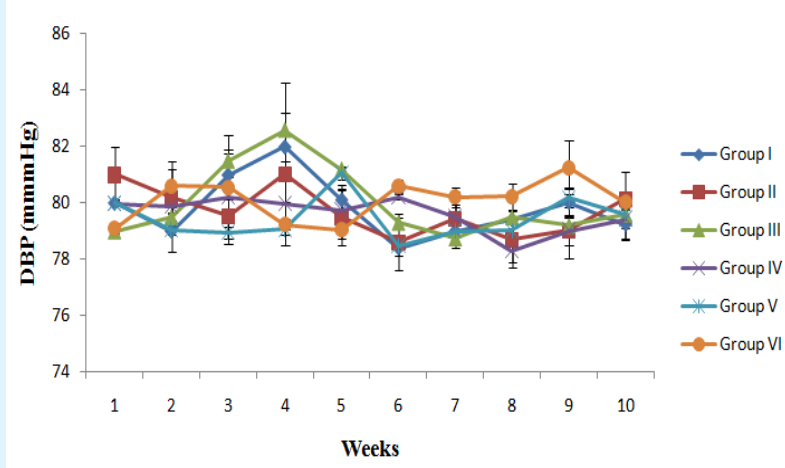

Figure 2: Effect of salt diet and nutraceutical supplementation on diastolic blood pressure of saltloaded rats
Week 1-6: salt diet only, week 6-10: salt diet plus supplements, Group I: salt loaded treated with $250 \mathrm{mg} / \mathrm{kg}$ of nutraceutical, Group II: salt loaded treated with $500 \mathrm{mg} / \mathrm{kg}$ of nutraceutical, Group III: salt loaded treated with $10 \mathrm{mg} / \mathrm{kg}$ of nifedipine, Group IV: salt loaded treated with $500 \mathrm{mg} / \mathrm{kg}$ of nutraceutical + $10 \mathrm{mg} / \mathrm{kg}$ of nifedipine, Group V: salt-loaded untreated, Group VI; control.

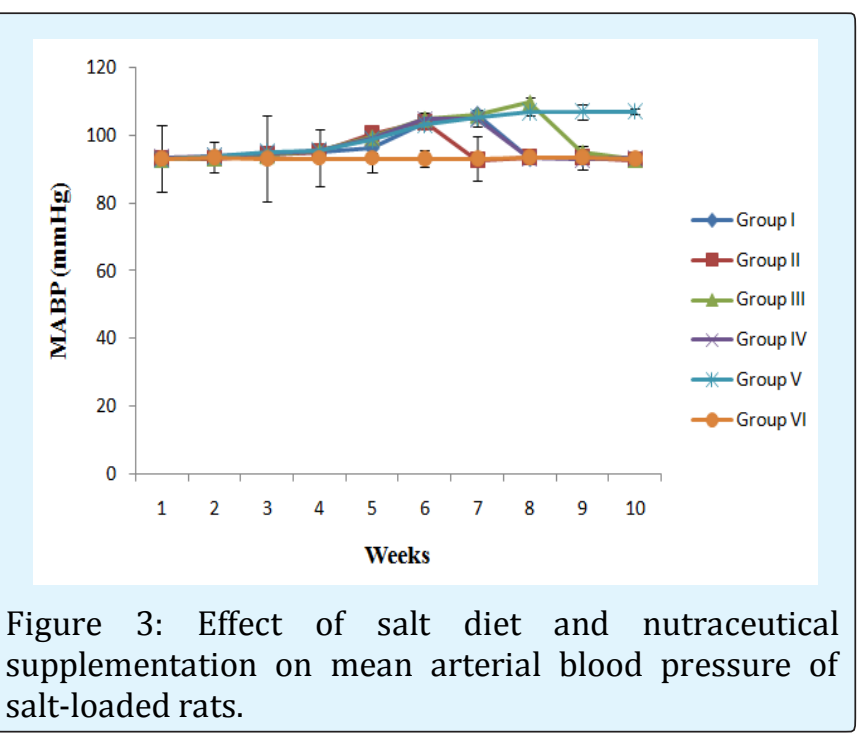

Week 1-6: salt diet only, week 6-10: salt diet plus supplements, Group I: salt loaded treated with $250 \mathrm{mg} / \mathrm{kg}$ of nutraceutical, Group II: salt loaded treated with $500 \mathrm{mg} / \mathrm{kg}$ of nutraceutical, Group III: salt loaded treated with $10 \mathrm{mg} / \mathrm{kg}$ of nifedipine, Group IV: salt loaded treated with $500 \mathrm{mg} / \mathrm{kg}$ of nutraceutical + $10 \mathrm{mg} / \mathrm{kg}$ of nifedipine, Group V: salt-loaded untreated, Group VI: control.

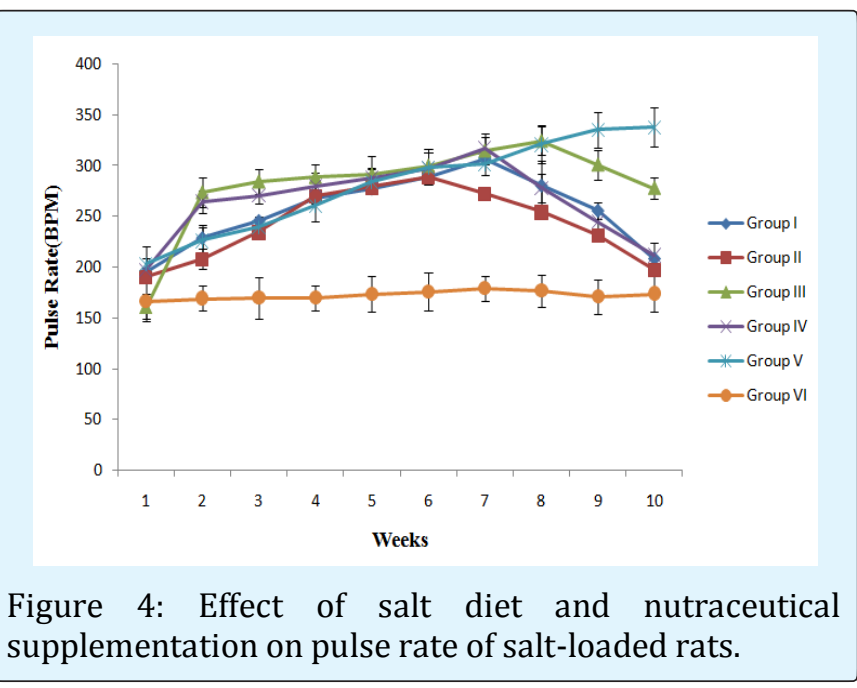

Week 1-6: salt diet only, week 6-10: salt diet plus supplements, Group I: salt loaded treated with $250 \mathrm{mg} / \mathrm{kg}$ of nutraceutical, Group II: salt loaded treated 


\section{International Journal of Biochemistry \& Physiology}

with $500 \mathrm{mg} / \mathrm{kg}$ of nutraceutical, Group III: salt loaded treated with $10 \mathrm{mg} / \mathrm{kg}$ of nifedipine, Group IV: salt loaded treated with $500 \mathrm{mg} / \mathrm{kg}$ of nutraceutical + $10 \mathrm{mg} / \mathrm{kg}$ of nifedipine, Group V; salt-loaded untreated, Group VI: control.

The result of the mean percentage weight gain of the rats in all the groups and mean percentage reduction in SBP, MABP and PR are presented in Figures 5 and 6 respectively. The result indicated that the salt-loaded untreated and salt-loaded treated with $10 \mathrm{mg} / \mathrm{kg}$ of nifedipine are gained more weight $(42.4 \pm 1.76 \%)$ and $(37.02 \pm 0.88 \%)$ respectively than all other groups. The group that gained the least weight $(18.3 \pm 0.65 \%)$ was the group supplemented with $500 \mathrm{mg} / \mathrm{kg}$ of nutraceutical.

The result also showed that supplementation decreases the SBP, MABP and PR, rats supplemented with $500 \mathrm{mg} / \mathrm{kg}$ of nutraceutical have the highest \% reduction $(27.42 \pm 2.52 \%)$ and $(12.85 \pm 1.22 \%)$ in SBP and MABP respectively while groups supplemented with $10 \mathrm{mg} / \mathrm{kg}$ of nifedipine have the lowest \% reduction $(23.22 \pm 0.97 \%)$ and $(10.23 \pm 0.76 \%)$ in SBP and MABP respectively.

It was observed that rats supplemented with $500 \mathrm{mg} / \mathrm{kg}$ of nutraceutical $+10 \mathrm{mg} / \mathrm{kg}$ have the highest $\%$ reduction $(47.78 \pm 0.05 \%)$ in PR while group supplemented with $10 \mathrm{mg} / \mathrm{kg}$ of nifedipine have the lowest \% reduction (39.46 $\pm 0.24 \%)$ in PR.

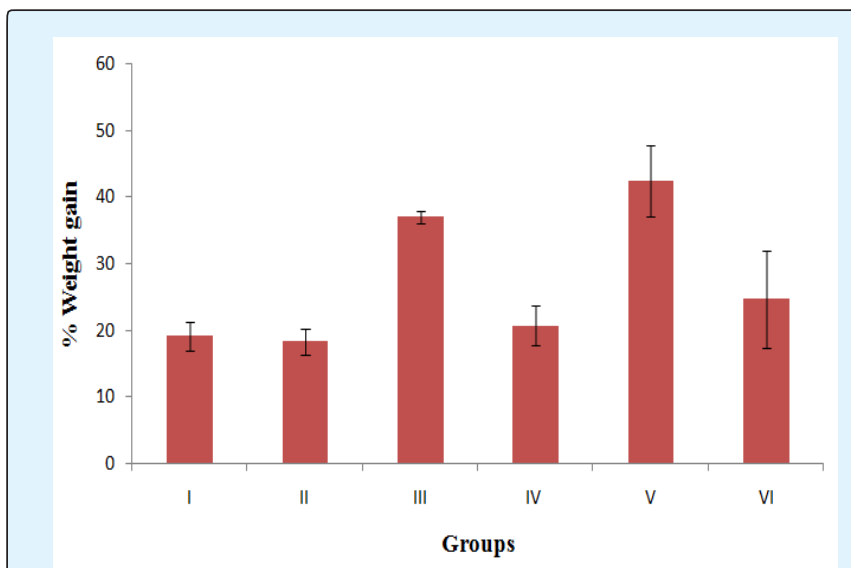

Figure 5: The mean percentage weight gain of saltloaded rats treated with nutraceutical

Group I: salt loaded treated with $250 \mathrm{mg} / \mathrm{kg}$ of nutraceutical, Group II: salt loaded treated with $500 \mathrm{mg} / \mathrm{kg}$ of nutraceutical, Group III: salt loaded treated with $10 \mathrm{mg} / \mathrm{kg}$ of nifedipine, Group IV: salt loaded treated with $500 \mathrm{mg} / \mathrm{kg}$ of nutraceutical + $10 \mathrm{mg} / \mathrm{kg}$ of nifedipine, Group V: salt-loaded untreated, Group VI: control.

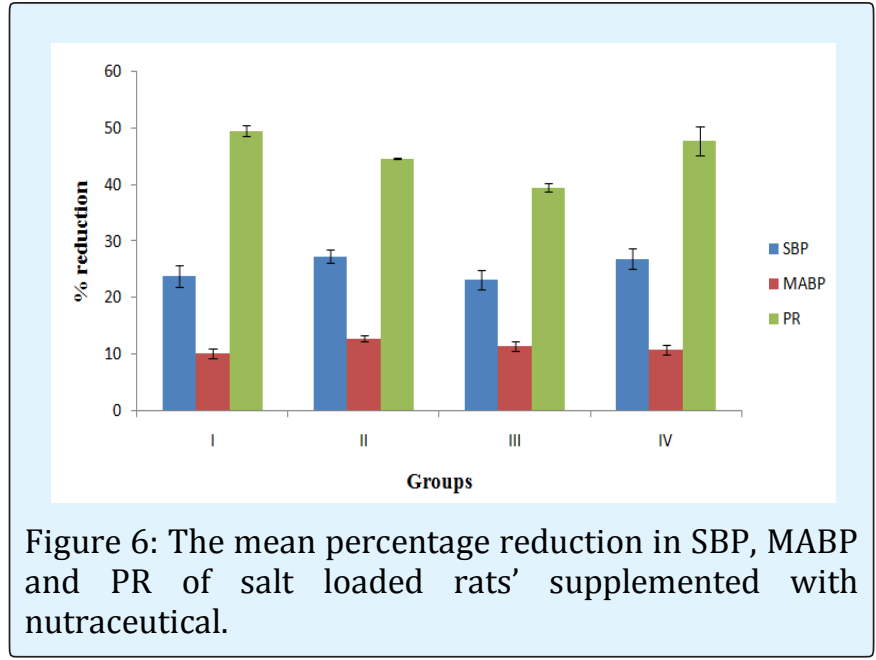

SBP-systolic blood pressure, MABP-mean arterial blood pressure, PR-pulse rate, Group I: salt loaded treated with $250 \mathrm{mg} / \mathrm{kg}$ of nutraceutical, Group II: salt loaded treated with $500 \mathrm{mg} / \mathrm{kg}$ of nutraceutical, Group III: salt loaded treated with $10 \mathrm{mg} / \mathrm{kg}$ of nifedipine, Group IV: salt loaded treated with $500 \mathrm{mg} / \mathrm{kg}$ of nutraceutical $+10 \mathrm{mg} / \mathrm{kg}$ of nifedipine, Group V: saltloaded untreated, Group VI: control.

The result of mean percentage protection against atherogenesis is presented in Figure 7. The result indicated $(76.5 \pm 2.13 \%)$ mean average percentage protection in all the groups supplemented with nutraceutical while non-supplemented group gave the lowest (13.02 $\pm 1.77 \%)$ protection against atherosclerosis.

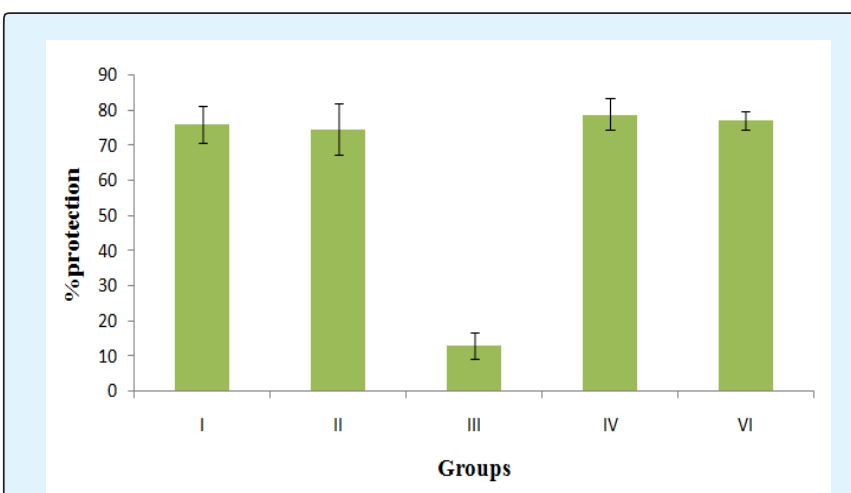

Figure 7: Mean percentage protection of nutraceutical against atherosclerosis.

Group I: salt loaded treated with $250 \mathrm{mg} / \mathrm{kg}$ of nutraceutical, Group II: salt loaded treated with $500 \mathrm{mg} / \mathrm{kg}$ of nutraceutical, Group III: salt loaded treated with $10 \mathrm{mg} / \mathrm{kg}$ of nifedipine, Group IV: salt loaded treated with $500 \mathrm{mg} / \mathrm{kg}$ of nutraceutical + $10 \mathrm{mg} / \mathrm{kg}$ of nifedipine, Group V: salt-loaded untreated, Group VI: control. 


\section{International Journal of Biochemistry \& Physiology}

\section{Discussion}

The onset of hypertension is caused by complex interaction between genetic predisposition and environmental risk factors [9]. Hypertension is associated with the incidence of arthrosclerosis [10]. Thus, development of therapeutic/management strategies that may delay the onset and prevent complications associated with hypertension is critical to improve the life of patients with hypertension. This study was designed to formulate an antioxidant rich nutraceutical from locally available foodstuff and to evaluate whether supplementation with antioxidant rich nutraceutical could play vital role in delaying the onset and progress of hypertension. In our model, a diet containing $8 \%$ salt was used to induce hypertension in Wistar albino rats for a period of 6 weeks. Our model fit the scenario of high salt diet caused hypertension in experimental rats and humans $[11,12]$.

The results of this study indicated that salt-loading to rats for 6 weeks increased blood pressure and body weight. The mechanism of high salt diet-induced hypertension could be attributed to increase concentration of sodium in circulation which turned activates sympathetic nervous system and reninangiotensin-aldesterol-system (RAAS) as well as increased signaling through the mineralocorticoid receptors (MR) $[13,14]$. These may lead to increase production of reactive oxygen species (ROS) and oxidative stress, and finally contribute to aetiopathology of insulin resistance, high blood pressure, impaired glucose homeostasis and dyslipidaemia [15].

The finding confirms the reports that salt loading to various strains of rats such as Sprague-Dawley rats, Wistar rats and Dahl salt-sensitive rats result in increased mean arterial blood pressure $[11,12,16]$.

Elevation of systolic blood pressure (SBP) indicates the risk of cardiovascular disease which is more important than increase in diastolic blood pressure (DBP) and is more difficult to control than DBP [9]. The lack of effect on DBP observed in this study could be attributed to salt diet does not have much effect on resting state of the heart during cardiac relaxation.

The blood pressure lowering effect of nutraceutical could be attributed to combine effects of the nutraceutical with calcium channel blocking activity and diuretic effect [17]. It may also be attributed to high level of flavonoids, in the nutraceutical as flavonoids inhibit the activity of angiotensin-converting enzyme (ACE) which raises blood pressure [18]. Other possible mechanism could be due to the presence of antioxidant vitamins and minerals in the nutraceutical thereby exhibiting antioxidant activity either by serving as nucleophilic species or scavenge superoxide anions as reported by [19].

The highest percentage weight gain observed in nonsupplemented rats with hypertension. The possible mechanism by which salt diet increases body weight could be attributed to sodium levels can activate RAAS via increase in sympathetic outflow thereby stimulating adipokines that contribute to increase in abdominal weight [20]. The lowest percentage weight gain was observed in rats supplemented with $500 \mathrm{mg} / \mathrm{kg}$ of nutraceutical. The weight lost could be attributed to anti-obesity effects of the nutraceutical through modification of lipid and carbohydrate metabolism, increased insulin sensitivity, and regulation of both appetite and adipocytokines [21]. Other possible mechanism could be attributed to inhibitory effects of the nutraceutical in proliferation, differentiation, angiogenesis in pre-adipocytes and induction of apoptosis in mature adipocytes [22,23]. Other possibility could be associated with the regulation of brown adipose tissue metabolism and increase thermogenesis, decrease adiponectin and leptin gene expression in adipocytes [24,25].

\section{Conclusion}

Antioxidant rich nutraceutical lowered the blood pressure and body weight and may have promising effect in the management of cardiovascular complications of hypertension and obesity.

\section{References}

1. Wolf-Maier K, Cooper RS, Banegas JR, Giampaoli S, Hense $\mathrm{H}$, et al. (2003) Hypertension prevalence and blood pressure levels in 6 European countries, Canada, and the United States. JAMA 289(18): 2363-2369.

2. Whitworth JA, WHO (2003) 2003 World Health Organization (WHO)/International Society of Hypertension, statement on management of hypertension. J Hypertens 21(11): 1983-1992.

3. Godfraind T (2005) Antioxidant effects and the therapeutic mode of action of calcium channel blockers in hypertension and atherosclerosis. Philos Trans R Soc Lond Biol Sci 360(1464): 22592272.

4. Cappuccio FP, Micah FB, Emmett L, Kerry SM, Antwi S, et al. (2004) Prevalence, detection, management and control of hypertension in Ashanti, West Africa. Hypertension 43(5): 1017-1022. 


\section{International Journal of Biochemistry \& Physiology}

5. Kearney PM, Whelton M, Reynolds K, Muntner $\mathrm{P}$, Whelton PK, et al. (2005) "Global burden of hypertension: analysis of worldwide data. Lancet 365(9455): 217-223.

6. Chobanian AV, Bakris GL, Black HR, Cushman WC, Green LA, et al. (2003) The seventh report of the JNC on prevention detection, evaluation and treatment of high blood pressure. the JNC 7 report. JAMA 289(19): 2560-2572.

7. Dietz KJ, Jacob S, Oelze ML, Laxa M, Tognetti V, et al. (2006) The function of peroxiredoxins in plant organelle redox metabolism. J Exp Bot 57(8): 16971709.

8. Bilbis LS, Muhammad SA, Saidu Y, Adamu Y (2012) Effect of vitamin $A, C$ and E supplementation in the treatment of metabolic syndrome in albino rats. Biochemistry Research International 12: 678582.

9. Hayman LL (2000) Abnormal blood lipids: is it environment or is it genes? J Cardiovasc Nurs 14(2): 39-49.

10. Nwanjo HU (2005) Efficacy of aqueous extract of Vernonia amydalina in plasma lipoprotein and oxidative status in diabetic rats. Niger J Physiol Sci 20(1-2): 39-42.

11. Ogihara T, Asano T, Ando K, Sakoda H, Anai M, et al. (2002) High-salt diet enhances insulin signaling and induces insulin resistance in Dahl salt sensitive rats. Hypertension 40(1): 83-89.

12. Tian N, Thrasher KD, Gundy PD, Hughson MD, Manning RD (2005) Antioxidant Treatment prevents renal damage and dysfunction and reduces arterial pressure in salt-sensitivity hypertension," Journal of Hypertension. 45(5): 934939.

13. Pawloski-Dahm CM, Gordon FJ (1993) Increased dietary salt sensitizes vasomotor neurons of the rostral ventrolateral medulla. Hypertension 22(6): 929-933.

14. Stas S, Whaley-Connell A, Habibi J, Appesh L, Hayden MR, et al. (2007) Mineralocorticoid receptor blockade attenuates chronic over expression of the rennin-angiotensin-aldosterone system stimulation of reduced nicotinamide adenine dinucleotide phosphate oxidase and cardiac remodeling. Endocrinology 148(8): 37733780 .
15. Fujita T (2010) Mineralocorticoid receptors, saltsensitive hypertension, and metabolic syndrome. Hypertension 55(4): 813-818.

16. Kagota S, Tamashiro A, Yamaguchi Y, Sugiura $R$, Kuno T, et al. (2001) Down regulation of vascular soluble guanylate cyclase induced by high salt intake in spontaneously hypertensive rats. $\mathrm{Br} \mathrm{J}$ Pharmacol 134(4): 737-744.

17. Houston MC (2005) Nutraceuticals, Vitamins, Antioxidants, and Minerals in the Prevention and Treatment of Hypertension. Prog Cardiovasc Dis 47(6): 396-449.

18. Cook NC, Samman S (1996) Flavonoids-Chemistry, metabolism, cardio protective effects, and dietary sources. Journal of Nutritional Biochemistry 7(2): 66-76.

19. Rohilla A, Sonu (2013) Hypertension: Sources and Treatments. International Journal of Research Pharmacology Biomedical Science 4(1): 94-99.

20. Rahmouni K, Mark AL, Haynes WG, Sigmund CD (2004) Adipose depots specific modulation of angiotensinogen gene expression in diet induced obesity. Am J Physiol Endocrinol Metab 286(6): E891-E895.

21. Meydani M, Hasan ST (2010) Dietary polyphenols and obesity. Nutrients 2(7): 737-751.

22. Fukunchi Y, Hiramitsu M, Okada M, Hayashi S, Nabeno Y, et al. (2008) Lemon Polyphenol Suppress Diet-induced Obesity by Up-Regulation of mRNA Levels of the Enzymes Involved in beta- Oxidation in Mouse White Adipose Tissue. J Clin Biochem Nutr 43(3): 201-209.

23. Lee MS, Kim CT, Kim Y (2009) Green tea (-)epigallocatechin-3-gallate reduce body weight with regulation of multiple genes expression in adipose tissue of diet-induced obese mice. Ann Nutr Metab 54(2): 151-157.

24. Zulet MA, Puchau B, Hermsdorff $\mathrm{HH}$, Navarro C, Martínez JA (2008) Vitamin A intake is inversely related with adiposity in healthy young adults. J Nutr Sci Vitaminol (Tokyo) 54(5): 347-352.

25. Detopoulou P, Panagiotakos DB, Chrysohoou C, Fragopoulou E, Nomikos T, et al. (2010) Dietry antioxidant capacity and concentration of adiponectin in apparently healthy adults. Eur J Clin Nutr 64(2): 161-168. 